DOI: https://doi.org/10.32782/2410-0927-2020-12-11

УДК $821.111 .03-341$

Світлана Гончарук

\title{
ПОЕТИКА КОМІЧНОГО В ПАРОДІЙНІЙ ТВОРЧОСТІ РОАЛЬДА ДАЛА
}

В статті аналізовано особливості пародійної творчості Роальда Дала на основі його віршованої збірки дитячих віршів «Revolting Rhymes». Автор статті узагальнює відомості, які стосуються жанру пародії, простежує розвиток сюжетних ліній творів.

Місце пародійного начала у спадщині Роальда Дала займає важливе складове місце. Усім досліджуваним творам притаманний комічний стиль, для якого слова $є$ не лише засобом вираження змісту, а способом нового поетичного мовлення, спрямованого на «свого» читача. Проте, крім розважальної користі, ці твори несуть в собі серйозний зміст. Автор ховає під пародійною маскою об' єктивний світ, який стає фантастично-натуралістичним.

Пародійна поезія британського письменника Роальда Дала репрезентує незвичні сюжетні лінії, які поєднані 3 фольклорним матеріалом, звичними нам 3 дитинства героями. Текст віршованих казок слугує засобом впливу на читача, синтезуючи сучасні досягнення масової культури. Різноманітні словесно-художні коди переплетені, утворюючи своєрідний значеннєвий дискурс.

Характерними рисами пародійної творчості Роальда Дала є жанрова еволюція віршованих казок, порушення табуйованих тем. У композиційній структурі віршів Роальда Дала простежуємо, напруженість інтриги, втаємничення змісту. При всій казковості сюжету вірші Дала відрізняють сучаснимиі деталі та мову головних героїв твору. Звертаючись до казкових мотивів, Р. Дал трансформував їх, вводив притаманні сьогоденню речі, дрібниці побуту.

Комізм на рівні текстів віршів Р. Дала реалізовано за допомогою мовних засобів для створення ситуативного та лінгвістичного комізму: епітетів, метафор, порівнянь, гіпербол. Завдяки вживанню сленгу, вульгаризмів, твори набувають іронічного колориту.

Сприйняття повідомлень як персонажами всередині тексту, так і читачем, визначається ступенем інформованості кожного з них. Для індивідуального стилю Р. Даля є характерним широке використання засобів друкарської виразності: різних шрифтів, курсиву, дужок і капіталізації. Мову Роальда Даля вирізняє простота i лаконічність, яка досягається завдяки підбору слів, що забезпечують точність викладу думки.

Ключові слова: комічне, пародія, іронічний колорит, казковий сюжет, фольклорна основа.

Вступ. Кожен народ досконало пізнає себе коли занурюється у читання художньої літератури. Національна література завжди є нерозривно пов'язана з фольклором, який накопичує високі духовні цінності. Казка $є$ одним з найдавніших жанрів народної творчості, за допомогою якої читач має змогу поринути в чарівний світ, забувши про рутину сьогодення. 'Казка - це настільки універсальна форма, що може інтегруватись не лише в писемну літературу, а й у авторську творчість окремого письменника" [3, с. 140]. Яскравим представником англійської літератури, який створив різні жанрові різновиди казок, є Роальд Дал, якого називали Шекспіром дитячої літератури. Його прозові казки входять до переліку найкращих творів для дітей, проте віршовані казкові твори залишаються все ще залишаються недослідженими.

Об’сктом нашого дослідження стали віршовані твори Роальда Дала “Revolting Rhymes”. Ця збірка - це пародія на традиційні народні казки у формі віршів. Шість дитячих казок “Червона Шапочка", "Троє поросят", “Джек і бобове дерево”, "Білосніжка і сім гномів", “Золотоволоска і три ведмеді”, “Попелюшка” отримують неповторну інтерпретацію та містять незвичний кінець замість традиційно щасливих.

Мета роботи - дослідити поетику комічного в пародійній збірці Р. Дала "Revolting Rhymes" та художні засоби, що використовувалися при іï написанні.

Методи та методики дослідження. Цільові установки й завдання визначили комплексну методику аналізу фактичного матеріалу. Поряд із загальними методами наукового пізнання (описом, узагальненням, індукцією, дедукцією), були використані також методи порівняльного, стилістичного та контекстуального аналізу творів на різних мовних рівнях.

Результати дослідження. Ще з дитинства, коли ми слухали казки, які нам розказували наші батьки, ми були певні, що кожна казка повинна закінчуватися щасливо. Проте, немає нічого незмінного, і з часом утворюються нові незвичні жанрові інтерпретації, які поєднують комічне та трагічне. "Бачення (сприйняття) в житті прекрасного, потворного, героїчного, низького,

(C) Гончарук C., 2020 
трагічного, комічного виокремлює якийсь життєвий кавалок (опосередковує його), вимагає осмислення, переживання і таким чином ніби посуває в царину творчого освоєння. Естетичні потреби, які спонукають до творчості, це не тільки потреба в красі (вона-домінуюча, ключова для групи потреб, які вимагають від людини реалізації), це потреба, користуючись природним даром, створити щось таке, що для всіх інших людей засвідчить цінність творця" [3, с. 13].

Однією з естетичних категорій, метою якої стає висміювання невідповідності змісту і форми, є категорія комічного. Ця категорія містить різноманітні жанрові форми, серед яких чільне місце посідає пародія. ‘Всі жанри, без виключення, можуть стати об’єктом пародії: від багатотомної епопеї до афоризму. Будь-який із жанрів може включати в себе пародію як частину, утворюючи 3 нею єдине словарно-композиційне ціле. Пародія має свій контекст відносин 3 кожним жанром окремо і зі всіма жанрами в цілому. Більш того - пародія здатна об'єктивувати сам феномен жанру, комічно демонструючи його специфіку” [4, с. 13]. Саме загострення деяких рис та засобів роблять наслідуваний твір смішними.

Серед дослідників пародії необхідно виділити таких мовознавців, як П. Берков, А. Морозов, В. Новиков, Ю. Тинянов. Переважна більшість науковців стверджує, що термін "пародія" - це художнє наслідування стилю письменника або літературного напрямку з метою його висміювання. Узагальнене визначення цього жанру дає відомий літературознавець Петро Васильович Білоус: "Пародія (грец. parodia - жартівлива переробка) - жанр сатиричної чи гумористичної літератури, оснований на перебільшено комічному наслідуванні твору якогось автора або літературного напряму““[1, с. 325].

Особливістю реалізації пародіювання Дала є назва збірки - "Хуліганські казки” або "Бандитські вірші". Ця назва в метафоричній формі імплікує прихований зміст усіх віршованих творів. Художній світ знайомих нам з дитинства казок “Попелюшка", “Білосніжка і сім гномів”, “Троє поросят" та ін. отримує, з легкої руки Роальда Дала, нові сюжетні лінії. Це авантюрні, 3 фольклорними елементами сюжети, у яких автор намагається змінити усталений хід подій.

Ритми поезії - це втілення ритмів нашого життя. Причому ритми життя мають безліч складників: кожен поет відбиває ритм зовнішній, властивий природі, суспільству, епосі, i власний, внутрішній, властивий лише одному поетові. Кожен геніальний поет має свій неповторний голос - ту інтонацію (утворену ритмом), звучання всіх поезій, яке вирізняє саме цього поета, за якою ми одразу пізнаємо автора [3].

Загалом, твори Роальда Дала визначають як твори 3 недостатньо дослідженими жанровими формами. На основі фольклору, який був трансформований авторською свідомістю, Роальд Дал створив низку цікавих та оригінальних віршів. Ці твори - дивні історії, розказані в суто англійській манері. У них є чорний гумор, іронія, сарказм, які виникають у ставленні читачів до героїв, які дивакуваті. 3 цією метою Роальд Дал використовує у своїх віршах традиційні розміри, повтори, символи та інші засоби.

Більшість його поетичних творів написані традиційною схемою римування aabbccdd, коли чергуються кінцеві звуки. Це основна модель римування, яка повністю відповідає темі та передбачуваній аудиторії. Використання римованих куплетів допомагає створити швидкий темп та легкий ритмічний тон, які легко запам'ятовують діти:

As soon as Wolf began to feel

That he would like a decent meal,

He went and knocked on Grandma's door.

When Grandma opened it, she saw

The sharp white teeth, the horrid grin,

And Wolfie said, "May I come in?" (Little Red Riding Hood and the Wolf)

3 метою передачі комічного характеру своїх віршованих казок, Роальд Дал використовує низку знаків пунктуації та графічних символів. Так, капіталізація в творах Дала слугує засобом маркування оцінної конотації, показує не традиційність предмета чи явища. Наприклад:

Ghastly frightening thing occurred-

Not far above his head he heard

A big deep voice, a rumbling thing 
That made the very heavens ring.

It shouted loud, "FEE FI FO FUM

I SMELL THE BLOOD OF AN

ENGLISHMAN!" (Jack and Beanstalk)

Важливу роль у передачі ставлення автора до героїв його твору відіграють пунктуаційні знаки. Вони слугують своєрідними натяками на підтекст твору, підказками щодо емоційної реакції читача. Так, знак оклику Р. Дал використовує для передачі емоцій головних героїв, щоб посилити їхню емоційну експресію:

'Oh mum! he gasped. 'Believe you me

'There's something nasty up our tree!

'I saw him, mum! My gizzard froze!

'A clever nose!'his mother hissed.

'You must be going round the twist!' (Jack and Beanstalk)

Кома у досліджуваних віршах показує динамічність твору, підсилює їх контрастність. Письменник часто використовує дужки, які несуть функцію виділення і слугують для вираження ставлення автора до подій:

They pawned their watches, sold the car

They borrowed money near and far

(For much of it they had to thank

The Manager of Barclays Bank).(Snow White and the Seven Dwarfs)

When little Snow-White's mother died

The King, her father, up and cried

"Oh, what a nuisance! What a life!

Now I must find another wife".

(It's never easy for a King

To find himself that sort of thing.) (Snow White and the Seven Dwarfs)

За допомогою курсиву Р. Дал створює іронічний ефект, дає читачеві авторську підказку, робить графічний наголос. Три крапки $\epsilon$ маркером схвильованої мови та вказують на незавершеність:

He gazed aloft. He wondered when

The dreaded words would come ... And

Then...

From somewhere high above the ground

There came a frightful crunching sound. (Jack and Beanstalk)

Досліджувані поетичні твори наслідують форми народних казок: тематика збігається 3 оригіналами. Літературна пародія Р. Дала відображає ті ж самі форми і засоби, які були представлені у народних казках. Проте, поет змінює техніку оповіді, відступає від звичного сюжету, трансформує події у незвичний для читача спосіб. Так, знайомій нам 3 дитинства "Червоній шапочці" головна героїня і кінці твору виймає пістолет, вбиває сама вовка і через деякий час одягає пальто з вовчої шкури. У “Попелюшці” головна героїня виходить заміж не за принца, а за торгівця варенням, а у “Трьох поросятах" з'являється червона шапочка, яка не лише вбиває вовка, але й жорстоко розправляється з третім поросям, і робить 3 його шкіри валізу.

Композиція також виступає важливим елементом пародіювання в "Хуліганських казках". Комізм у віршових казках Р. Дала може реалізовуватися як на рівні окремих фрагментів висловлювань художнього тексту, так і нарівні цілісного твору. При цьому сукупність комічності окремих фрагментів створює цілий текст з вмістом комічного. Проте, Дал значно поглибив і розширив проблематику досліджуваних казок за рахунок соціально-викривальних моментів. Так, у віршованій казці “Білосніжка і сім гномів" автор стверджує, що азартні ігри не $\epsilon$ гріхом, за умови якщо ви постійно виграєте гроші:

Each Dwarf and Snow-White got a share

And each was soon a millionaire

Which shows that gambling's not a sin 
Provided that you always win. (Snow White and the Seven Dwarfs)

Важливим елементом казки є кінець, який, за класикою жанру, повинен обов'язково бути щасливим для головних героїв. Проте, у “Трьох поросятах” епілог звучить дуже повчально для дітей: не можна довіряти молодим дівчатам з верхівки суспільства, бо це може вартувати життя простому смертному:

Ah, Piglet, you must never trust

Young ladies from the upper crust.

For now. Miss Rididng Hood, one notes,

Not only has two wolfskin coats,

But when she goes from place to place,

She has a PIGSKIN TRAVELLING CASE. (The Three Little Pigs)

Звичайно, як і оригінальних казках існує поділ на хороших (poor Snow-White, darling little Cinderella) і поганих (Miss Maclahose, Ugly Sisters) героїв. Роальд Дал вдало описує головних героїв, вкладаючи в дитячі голови жартівливі слова або ребуси. 3 цією метою він використовує низку епітетів, описових слів, а також порівняння, гіперболи.

Compared with her old Grandmamma,

She's going to taste like caviar. (Little Red Riding Hood and the Wolf)

He wrote to every magazine

And said, "I'm looking for a Queen."

At least ten thousand girls replied

And begged to br the royal bride. (Snow White and the Seven Dwarfs)

Діапазон пародійного сміху Р. Дала достатньо широкий: він пародіює особливості зовнішності, одягу, нахилів і звичок героїв віршованих творів за допомогою гумористичного обігрування. Наприклад, коли королева питає чарівне дзеркало, які страви будуть на обід, воно відповідає:

The thing would answer in a trice

"Today it's scrambled eggs and rice". (Snow White and the Seven Dwarfs)

B “Попелюшці” бал автор замінює на дискотеку, а головна героїня з доброї, скромної дівчини перетворюється на грубу. Жорстоку особу:

'There is a Disco at the Palace!

'The rest have gone and I am jealous!

'I want a dress! I want a coach!

'And silver slippers, two of those! (Cinderella)

Звертаючись до казкових мотивів, Р. Дал трансформував їх, вводив притаманні сьогоденню речі, дрібниці побуту. Водночас у творах Дала знаходить відбиток матеріальність світу через низку деталей, які ми зустрічаємо в сучасному світі: порохотяг, динаміт, дискотека. Так, наприклад, у вірші “Джек і бобове стебло” мама головного героя б’є його за допомогою ручки від порохотяга:

Then summoning up all her power,

She beat the boy for half an hour,

Using (and nothing could be meaner)

The handle of a vacuum-cleaner. (Jack and Beanstalk)

Мовні засоби вираження комізму дають нам змогу відносити той чи інший твір до певного виду комічного за допомогою використання образних порівнянь, метафор, метонімії та ін. Крім того, завдяки вживанню сленгу, вульгаризмів, твір набуває іронічного колориту:

Then dad cries, 'Golly-gosh! Gee-

Whizz!

'Oh cripes! How hot this porridge is!

'Let's take walk along to eat.' (Goldilocks and the Three Bears)

You'd think by now this little skunk

Would have the sense to do a bunk.

But no. I very much regret 


\section{She hasn't nearly finished yet. (Goldilocks and the Three Bears)}

Саме через вульгаризми ця збірка віршів була заборонена в Австралії. На думку австралійських чиновників дітям не слід читати такі твори. Проте, всі ми добре знаємо, як діти люблять так звані “страшилки” та всілякі заборони. Тому, цей пласт лексики сприяв значній популярності збірки "Revolting Rhymes".

Висновки. Поєднання курйозного зі серйозним, комічного з трагічним - ці чинники визначають незаперечну самобутність віршованих казок Роальда Дала. У його збірці "Бандитські вірші" сформувалися такі сюжетні лінії, які несуть чималий запас гумору та дотепності. Завдяки фольклорній основі твори Р. Дала захоплюють, дають можливість повеселитись, i, водночас, щось пізнати нове.

Комізм на рівні всього тексту представлений у зображенні двох вимірів: реального й ippeального. Пародійність Роальда Дала виражає його погляд на дійсність, у якій він вбачає багато абсурду. Маркерами комізму в віршах Р. Дала $\epsilon$ різні графічні засоби, такі як капіталізація, дужки, курсив, емфатичний наголос, коментар. Також Роальд Дал майстерно використовує мовні засоби для створення ситуативного та лінгвістичного комізму.

\section{References}

1. Bilous, Petro. 2011. Vstup do literaturoznavstva. Kyiv: Akademiya

2. Dahl, Roald. "Revolting Rhymes" [Electronic resource]. - Mode of access: https://www.roalddahlfans.com/ dahls-work/books/revolting-rhymes/

3. Moklytsya, Maria. 2011. Vstup do literaturoznavstva. Lutsk: VNU imeni Lesi Ukrainky.

4. Novikov, Vladimir. 2019. Literatyrnaya parodiya. Moskva: Filologicheskii fakultet MGU.

Гончарук Светлана. Поэтика комического в пародийном творчестве Роальда Дала. В статье анализируются особенности пародийной творчества Роальда Дала на основе его стихотворного сборника детских стихов «Revolting Rhymes». Автор статьи обобщает сведения, касающиеся жанра пародии, прослеживает развитие сюжетных линий произведений.

Место пародийного начала в наследстве Роальда Дала занимает важное место. Всем исследуемым произведениям присущ комический стиль, для которого слова являются не только средством выражения содержания, но и способом новой поэтической речи, направленной на «своего» читателя. Однако, кроме развлекательной пользы, эти произведения несут в себе серьезный смысл. Автор прячет под пародийной маской объективный мир, который становится фантастически натуралистическим.

Пародийная поэзия британского писателя Роальда Дала представляет необычные сюжетные линии, которые сочетаются с фольклорным материалом, привычными нам с детства героями. Текст стихотворных сказок служит средством воздействия на читателя, синтезируя современные достижения массовой культуры. Различные словеснохудожественные коды переплетаются, образуя своеобразный смысловой дискурс.

Характерными чертами пародийной творчества Роальда Дала является жанровая эволюция стихотворных сказок, нарушение табуированных тем. В композиционной структуре стихов Роальда Дала прослеживается, напряженность интриги, таинственность содержания. При всей сказочности сюжета стихи Дала отличаются современными деталями языке главных героев произведения. Обращаясь к сказочных мотивам, Р. Дал трансформировал их, вводил присущие настоящему вещи, бытовые мелочи.

Комизм на уровне текстов стихов Р. Дала реализуется с помощью языковых средств для создания ситуативного и лингвистического комизма: эпитетов, метафор, сравнений, гипербол. Благодаря применению сленга, вульгаризмов, произведения приобретают иронический колорит.

Восприятие сообщений как персонажами внутри текста, так и читателем, определяется степенью информированности каждого из них. Для индивидуального стиля Р. Даля характерно широкое использование средств печатной выразительности: различных шрифтов, курсива, скобок и капитализации. Язык Роальда Даля отличает простота и лаконичность, которая достигается благодаря подбору слов, обеспечивающих точность изложения мысли.

Ключевые слова: комическое, пародия, ироничный колорит, сказочный сюжет, фольклорная основа.

Honcharuk Svitlana. Poetics of Comical in the Roald Dahl's Mockery Works. The article analyzes the features of Roald Dahl's parody on the basis of his poetic collection of children's poems "Revolting Rhymes". The author of the article summarizes the information relating to the genre of parody, traces the development of story lines.

The place of parody occupies an important place in the Roald Dahl's works. All researched works are characterized by a comic style, for which words are not only the means of expressing content, but also a way of new poetic speech aimed at "their" reader. However, in addition to entertaining benefits, these works carry a serious meaning. The author hides the objective world under a parody mask that becomes fantastically naturalistic.

The mock poetry of the British writer Roald Dahl represents unusual plot lines that are combined with folklore material. The main characters have been familiar to us since our childhood. The text of poetic tales serves as a means of 
impact on the reader, synthesizing the modern achievements of mass culture. Various verbal and artistic codes are intermingled, forming a kind of semantic discourse.

The characteristic features of Roald Dahl's parody are the genre evolution of poetic fairy tales, the violation of taboo topics. One can trace the intensity of intrigue, the mystery of the content in the compositional structure of his rhymes. All Dahl's verses differ in modern details and the language of the main characters. Turning to fairy-tale motifs, R. Dahl transformed them, introduced modern things, household trifles.

The comicality of R. Dahl's texts is realized with the help of linguistic means of creation situational humor: epithets, metaphors, similes, hyperbole. The work acquires an ironic color due to the use of slang and vulgarisms.

The perception of messages by both the characters within the text and the reader is determined by the degree of awareness of each of them. R. Dahl's individual style is characterized by the widespread use of print expressiveness: various fonts, italics, brackets and capitalization. Roald Dahl's language is characterized by simplicity and conciseness, which is achieved through the selection of words that ensure the accuracy of the opinion.

Key words: comic, parody, ironic flavor, fairy tale plot, folklore basis.

DOI: https://doi.org/10.32782/2410-0927-2020-12-12

УДК $811.11 ’ 42-11$

Оксана Гураль

\section{КРЕАТИВНА ЕКСПРЕСИВНІСТЬ АНГЛОМОВНОГО ПОСТМОДЕРНІСТСЬКОГО РОМАНУ У СВІТЛІ ТЕОРІЇ КОНЦЕПТУАЛЬНОГО БЛЕНДІНГУ}

Стаття присвячена розкриттю специфіки застосування теорії концептуального блендингу та теорії концептуальної метафори для аналізу глибинної семантики постмодерністського англомовного наративу. Оскільки когнітивний підхід до аналізу тексту розкриває значно більші можливості для тлумачення текстових тактик та індивідуально-авторських прийомів, він $є$ надзвичайно актуальним на сьогодні.

У статті подано зіставлення теорії концептуальної метафори та концептуального блендингу за декількома параметрами - порівняно спосіб застосування, одиниці аналізу, можливості, що з'являються при аналізі художнього тексту, а також їхній евристичний потенціал. В той час як перша концентрує свої зусилля на пошуку узагальнень у широкому спектрі метафоричних виразів, друга - фокусується на природі і особливостях специфічних прикладів, сприяючи виокремленню загальних принципів такої побудови. Незважаючи на те, що текст англомовного постмодерністського наративу значною мірою структурують конвенційні концептуальні метафори, вони зазнають різноманітних деформацій у процесі реалізації авторського творчого задуму, а саме - розширення, компресії, зміщення, використання раніше невикористаної частини концептуальної метафори.

У статті запропоновано аналіз новаторських концептів за допомогою теорії концептуального блендингу. Зокрема, проаналізовано появу додаткової семантики у емергентному просторі блендів LIFE IS ANTI-COMEDY, DOCTOR IS FIEND; розкрито особливості концептуальної моделі гіпотетичного судження алюзивного характеру: "But say Thumberlina had married the mole?”, висвітлено приріст значення у випадку складеного іменника ВОМВ ВАВY. Таким чином розкриваємо додаткові можливості теорії концептуального блендингу для моделювання глибинної семантики індивідуально-авторських висловів при зіставленні із теорією концептуальної метафори.

Ключові слова: концептуальний бленд, ментальний простір, концепт, концептуальна метафора, гіпотетичне судження.

Вступ. У сучасній авангардній художній літературі, до якої відносимо і романи М. Аміса, спостерігаємо прагнення до деконвенціоналізації стилістичних прийомів та наративних тактик, що у свою чергу стимулює процеси словотворення, збагачує мову додатковими смислами, відкриває нове бачення усталених речей. Хоча питання про новаторство більшості прийомів постмодерністської літератури залишається дискусійним: безліч з них запозичені з надбань попередників, прагнення до епатажу та деавтоматизації сприйняття штовхає автора на сміливе експериментаторство, застосування новаторських текстових прийомів та оповідних тактик, аналіз глибинної семантики яких потребує відповідного інструментарію.

У контексті когнітивного підходу до моделювання процесів читацької реконструкції тексту художнього твору Л. Зуншайн, Е. Семіно, П. Стоквела актуальним залишається застосування теорії концептуального блендингу Ж. Фоконьє, М. Тернера для пояснення семантики інноваційних художніх концептів, що втілюють авторський ідіосинкретичний спосіб інтерпретації дійсності. Когнітивна інтерпретація концептів такого типу виходить за мережі

(C) Гураль О., 2020 